\title{
Comparison of classical surgery and sutureless repair with DuraSeal or fibrin glue for duodenal perforation in rats
}

\author{
Siçanlarda oluşturulan duodenum perforasyonunda klasik cerrahi ile DuraSeal \\ ya da fibrin yapıștırıcı ile yapılan dikișsiz onarımların karşılaştırılması
}

\author{
Saliha KARAGÖZ AVCI, ${ }^{1}$ Serdar YÜCEYAR, ${ }^{1}$ Erman AYTAÇ, ${ }^{1}$ Onur BAYRAKTAR, ${ }^{1}$ \\ İlknur ERENLER, ${ }^{2}$ Hüseyin ÜSTÜN,${ }^{3}$ Hafize UZUN, ${ }^{4}$ Süphan ERTÜRK ${ }^{1}$
}

\section{BACKGROUND}

The purpose of the study was to compare classical primary suture repair and sutureless repair with fibrin glue or $\mathrm{Du}-$ raSeal adhesion barrier for the closure of duodenal perforation in rats.

\section{METHODS}

Forty adult female Wistar Albino rats weighing between 250-300g were randomly divided into four equal groups. Primary repair, primary repair and omentoplasty, or application of fibrin glue or DuraSeal adhesion barrier was performed in each of the four groups, respectively. The bursting pressure, tissue hydroxyproline levels and histopathology were evaluated.

\section{RESULTS}

Bursting pressure values of the primary repair and primary repair and omentoplasty groups were significantly higher than in the fibrin glue and DuraSeal groups $(\mathrm{p}<0.001)$. There were no significant differences between the experimental groups regarding hydroxyproline levels and histological parameters.

\section{CONCLUSION}

The sutureless methods (Fibrin glue, DuraSeal) have no superior effects when compared with the conventional repair techniques. We observed similar results between the sutureless repair groups; thus, DuraSeal can be considered an alternative to fibrin glue for this purpose. This suggestion must be supported with new studies, however, which would be planned with other wound healing markers and different designs.

Key Words: DuraSeal; duodenal perforation; fibrin glue; sutureless repair.

\section{$\boldsymbol{A M A C}$}

Bu çalışmada, sıçanlarda oluşturulan deneysel duodenum perforasyonunda klasik cerrahi teknikler ile adezyon bariyerleri olan DuraSeal ya da fibrin yapıştırıcıyla yapılan dikişsiz onarım tekniklerinin karşılaştırılması amaçlandı.

\section{GEREÇ VE YÖNTEM}

Kırk adet yetişkin, ağırlıkları 250-300 g arasında olan, dişi Wistar Albino sıçan rastgele dört adet eşit gruba ayrıldı. Primer onarım grubu, primer onarım ve omentoplasti grubu, fibrin yapıştırıcı uygulanan grup ve DuraSeal uygulanan grup. Doku iyileşmesini değerlendirmek amacıyla patlama basincı, doku hidroksiprolin seviyesi ve histopatolojik inceleme parametre olarak kullanıldı.

\section{BULGULAR}

Primer onarım, primer onarım ve omentoplasti gruplarının patlama basıncı değerleri fibrin yapıştırıcı ve DuraSeal grubu patlama basıncı değerlerine göre anlamlı olarak yüksekti $(\mathrm{p}<0,001)$. Biyokimyasal ve histolojik parametreler aç1sından tüm gruplar arasında anlamlı farklılık yoktu.

\section{SONUÇ}

Değerlendirdiğimiz dikişsiz onarım tekniklerinin konvansiyonel onarım tekniklerine üstün etkilerinin olmadığını gözlemledik. Dikişsiz onarım gruplarının sonuçları benzerdi. DuraSeal, fibrin yapıştırıcı gibi dikişsiz onarım alanında alternatif olabilir. Bu çıkarım farklı yara iyileşmesi belirteçleri ve farklı yöntemlerle planlanmış çalışmalarla desteklenmelidir.

Anahtar Sözcükler: DuraSeal; duodenal perforasyon; fibrin yapıştırıcı; dikişsiz tamir.

\footnotetext{
Departments of ${ }^{1}$ General Surgery, ${ }^{4}$ Biochemistry, Istanbul University

Cerrahpasa Faculty of Medicine, Istanbul; ${ }^{3}$ Department of Pathology, Ankara Training and Research Hospital, Ankara; ${ }^{2}$ Department of General Surgery, Kocaeli State Hospital, Kocaeli, Turkey.
} 
Duodenal perforation is an urgent situation, which usually necessitates surgical treatment. ${ }^{[1]}$ Peptic ulcer disease is the most common cause of duodenal perforation. ${ }^{[1,2]}$ Peptic ulcer disease is a frequent pathology that is caused by different disorders. Helicobacter pylori infection, nonsteroidal anti-inflammatory drugs, liver cirrhosis, hyperparathyroidism, and chronic pancreatitis are related to peptic ulcer disease. ${ }^{[3,4]}$ Definitive surgical approaches for the management of peptic ulcer became archaic after the use of proton pump inhibitors (PPIs) and expansion of $H$. pylori eradication therapy. In suitable conditions, primary repair is the preferable technique for duodenal perforations. ${ }^{[5]}$ Mortality and morbidity rates increase with delayed or failed surgery. Primary repair can be performed with classical open surgical technique or laparoscopy for duodenal peptic ulcer perforations. As a minimally invasive approach, sutureless repair of duodenal peptic ulcer perforation can simplify the technique and reduce the operation time.

Fibrin glue is used in clinical practice for duodenal perforations as an alternative sutureless repair via laparoscopic or endoscopic route. ${ }^{[6,7]}$ Fibrin glue is obtained from human fibrinogen concentrate and used to support wound healing. ${ }^{[8]}$ Fibrin glue mimics the last episode of coagulation. Thrombin and aprotinin are the main components of fibrin glue. Thrombin converts fibrinogen to fibrin. Factor XIII binds fibrin monomers with covalent links for clotting. Aprotinin is added to fibrin glue to prevent fibrinolysis. ${ }^{[8,9]}$ It has been reported that fibrin glue prevents hematoma formation and supports fibroblast activity and angiogenesis. ${ }^{[10,11]}$ Fibrin glue is being used in various pathologies including upper gastrointestinal tract perforations, ${ }^{[7,12]}$ fistulas ${ }^{[13,14]}$ and leaks. ${ }^{[15,16]}$

DuraSeal, which is an absorbable synthetic hydrogel, has blue solution and limpid solution. DuraSeal is a newly introduced material aiming to minimize leaks in various organs, such as cerebrospinal fluid in neurosurgery, air in thoracic surgery and blood in vascular surgery. ${ }^{[17-21]}$

The present experimental study aimed to compare the primary closure of duodenal defects by various techniques, notably primary repair, primary repair and omentoplasty, and DuraSeal or fibrin glue application.

\section{MATERIALS AND METHODS}

This study was performed after approval of the Ethics Committee of the Animal Care Review Board of Istanbul University, Experimental Medicine Research Institute. Adult female Wistar Albino rats, weighing 250-300 g, were obtained from Istanbul University Cerrahpasa Medical Faculty Experimental Animals Research Laboratory. The rats were cared for in accordance with the Guide for the Care and Use of Labo- ratory Animals (NIH Publication no. 86-23, revised 1985), maintained in colony cages ( 5 or 6 per cage) under controlled conditions of temperature $\left(28^{\circ} \mathrm{C}\right)$, light (10 h light: $14 \mathrm{~h}$ dark) and humidity $\left(50^{\circ} \mathrm{F} 5 \%\right)$. The rats were not permitted ad libitum access to standard lab chow and tap water starting from 12 hours before the surgery to the end of the experimental procedures. $10 \%$ dextrose solution $(10 \mathrm{ml} /$ day per rat) was given to the rats intraperitoneally during the postoperative period. Under ketamine chloride $(40 \mathrm{mg} / \mathrm{kg}$ ) anesthesia, the abdominal area was cleansed with povidone iodine solution after shaving. A median abdominal incision was performed. The anterior wall of the first part of the duodenum was perforated $(0.2 \mathrm{~cm})$ with a scalpel in every rat. The abdominal incision was closed with $3 / 0$ silk continuous sutures as a single layer. Forty rats were divided randomly into four weight-matched equal groups as follows: primary repair (with $4 / 0$ silk) group $(\mathrm{n}=10)$, primary repair and omentoplasty group $(\mathrm{n}=10)$, fibrin glue group $(n=10)$ (Beriplast $P$ combi set, ZLB Behring AG, Marburg, Germany; glue was sprayed on the perforated area without suturing), and DuraSeal group $(n=10)$ (Confluent Surgical, Inc., Waltham, MA; DuraSeal was sprayed on the perforated area without suturing). The components of fibrin glue and DuraSeal were carefully reconstituted and prepared according to the manufacturers' instructions. Sufficient $(0.25 \mathrm{ml})$ equal volume of fibrin glue and DuraSeal to entirely cover the perforated area was applied to a target surface. For covering the perforated area surfaces, the fibrin glue and DuraSeal were sprayed using the enclosed spray-tips. The rats were sacrificed on postoperative day 4 with overdose ether inhalation. After the measurement of bursting pressure levels of the repaired duodenal perforation site, an en-bloc excision of the repaired area together with $0.5 \mathrm{~cm}$ proximal and distal parts of the duodenum was performed. The excised part of the duodenum was divided into two equal tissue samples for histopathological and tissue hydroxyproline level analysis. For tissue hydroxyproline level investigation, samples were immediately immersed in liquid nitrogen and stored at $-70^{\circ} \mathrm{C}$ until being processed, and for histopathological evaluation, samples were fixed in $10 \%$ formaldehyde solution.

\section{Measurement of Bursting Pressure}

The abdominal incision of the rats was opened and the adhesions around the repaired area were preserved. The small intestine was ligated $2 \mathrm{~cm}$ distal from the repaired area of the duodenum. A catheter was inserted from the distal esophagus and fixed with $2 / 0$ silk suture. The prepared system was sunk into a bowl filled with water. Air was insufflated with $6 \mathrm{ml} / \mathrm{min}$ stable speed and the bursting pressure was measured with a sphygmomanometer. The pressure level when bubbles were first seen in the water was accepted as the bursting pressure level. 


\section{Hydroxyproline Assay}

The samples for hydroxyproline levels were weighed, cut into small pieces, and homogenized in a phosphate buffer to yield a $20 \%$ homogenate. Aliquots of the homogenate were added to an equal volume of 6 $\mathrm{N}$ hydrochloric acid, and hydrolyzed in Teflon-capped vials at $102^{\circ} \mathrm{C}$ for 16 hours. The hydroxyproline content of the tissue hydroxylates was determined spectrophotometrically by using the standard addition method developed by Kivirikko et al. ${ }^{[22]}$ (Hypopronosticon Kit lot/ch. B:E 92401; Organon Teknika B.V., Boxtel, Holland). Results were expressed in milligrams, such as in hydroxyproline/100 $\mathrm{mg}$ (wet weight).

\section{Histopathological Evaluation}

Duodenal tissue slices were then fixed in $10 \%$ buffered formalin and embedded in paraffin. Each section in $4 \mu \mathrm{m}$ thickness was stained with hematoxylin and eosin for light microscopic assessment. A certified pathologist scored samples in a blinded fashion. An arbitrary scope was given to each microscopic field at magnifications of $20 \mathrm{x}, 40 \mathrm{x}$ and $100 \mathrm{x}$. Ten representative areas from each section consisting of inflammation, revascularization, fibroblasts and collagen were examined, and scored to obtain the mean value. The parameters were graded on a 3-grade scale; mild, moderate or marked changes were indicated by an increase or decrease of 1, 2 or 3 grades, respectively.

\section{Statistical Evaluation}

All the values were expressed as the mean \pm SD. The data of bursting pressure and hydroxyproline content were analyzed by ANOVA test followed by a multiple comparison post- hoc test of Tukey. MannWhitney U test was used for the evaluation of the histopathological data. Values were considered as significant when $\mathrm{p}<0.05$. SPSS 12 (SPSS Inc. Chicago, IL, USA) was used for statistical analyses.

\section{RESULTS}

Six rats in total died: 3 each in the fibrin glue and the DuraSeal groups. One in each of these groups died immediately after induction of anesthesia. The other 4 rats died on postoperative day 2. Macroscopic leakage was observed in 2 rats of the fibrin glue group. However, no peritonitis and no leakage were observed in the other 2 rats in the DuraSeal group. Additional rats were included into the study to replace the rats that died. Intraabdominal adhesions were seen in all experimental groups. Bursting pressure levels are summarized in Table 1. There were no significant differences between the conventional repair groups (primary repair group, primary repair and omentoplasty group) with regard to bursting pressure levels. Bursting pressure levels of the conventional repair groups were significantly higher than in the sutureless repair groups (fibrin glue group and DuraSeal group)
Table 1. Bursting pressure levels according to treatment groups

\begin{tabular}{lc}
\hline Experimental groups & $\begin{array}{c}\text { Bursting pressure } \\
(\mathrm{mm} / \mathrm{Hg})\end{array}$ \\
\hline Primary repair $(\mathrm{n}=10)$ & $166 \pm 15.78$ \\
Primary repair+omentoplasty $(\mathrm{n}=10)$ & $185 \pm 42.49$ \\
Fibrin glue $(\mathrm{n}=10)$ & $84.29 \pm 11.34^{* * * . \# \#}$ \\
DuraSeal $(\mathrm{n}=10)$ & $91.43 \pm 6.90^{* * * . \ldots \#}$ \\
\hline
\end{tabular}

- Significance between the primary repair group and the other groups defined with $(*),(\mathrm{p}<0.001=* * *)$.

- Significance between the primary repair+omentoplasty group and the other groups defined with (\#), $(\mathrm{p}<0.001=\# \#)$.

Table 2. Tissue hydroxyproline levels according to the treatment groups

\begin{tabular}{lc}
\hline Experimental groups & $\begin{array}{r}\text { Tissue hydroxyproline } \\
\text { levels }(\mu \mathrm{g} / \mathrm{g} \text { wet tissue })\end{array}$ \\
\hline Primary repair $(\mathrm{n}=10)$ & $960.79 \pm 697.67$ \\
Primary repair+omentoplasty $(\mathrm{n}=10)$ & $490.45 \pm 224.97$ \\
Fibrin glue $(\mathrm{n}=10)$ & $599.12 \pm 447.35$ \\
DuraSeal $(\mathrm{n}=10)$ & $732.73 \pm 740.11$ \\
\hline
\end{tabular}

$(p<0.001)$. There were no significant differences between the fibrin glue and DuraSeal groups regarding bursting pressure levels.

Hydroxyproline levels of the experimental groups are summarized in Table 2. There were no significant differences between groups regarding tissue hydroxyproline levels.

Revascularization, inflammation and number of fibroblasts were similar between the primary repair and primary repair and omentoplasty groups. The collagen amount in the primary repair group was higher than in the other groups. Neoangiogenesis and number of fibroblasts were lower in the fibrin glue group. Irregular collagen arrangement was observed rarely in the DuraSeal group; however, there were no significant differences between groups with respect to histopathologic evaluation (Table 3).

\section{DISCUSSION}

Surgical treatments of duodenal perforations vary from primary repair to sutureless minimally invasive approaches..$^{[2,7,23]}$ The technical difficulties of suturing in laparoscopic and endoscopic approaches have led to research studies about sutureless repair for duodenal perforations..$^{[7,23,24]}$

Application of effective sutureless repairing techniques for intestinal perforations is being studied with new chemical agents to create a proper minimally invasive technique. The effective chemicals, which have adhesive barrier functions, would add to the newest therapeutic approaches in the field of minimally invasive surgery by simplifying the procedures. However, 
Table 3. Scores of the histopathological evaluation according to treatment groups

\begin{tabular}{lcccc}
\hline Groups & Inflammation & Revascularization & Fibroblast count & Collagen value \\
\hline Primary repair $(\mathrm{n}=10)$ & $1.5 \pm 0.53$ & $2.1 \pm 0.55$ & $2.5 \pm 0.53$ & $2.5 \pm 0.53$ \\
Primary repair + omentoplasty $(\mathrm{n}=10)$ & $1.6 \pm 0.7$ & $2.1 \pm 0.74$ & $2.2 \pm 0.63$ & $2.3 \pm 0.43$ \\
Fibrin glue $(\mathrm{n}=10)$ & $1.5 \pm 0.53$ & $2 \pm 0.67$ & $2.5 \pm 0.53$ & $2.5 \pm 0.53$ \\
DuraSeal $(\mathrm{n}=10)$ & $1.6 \pm 0.7$ & $2 \pm 0.82$ & $2.33 \pm 0.57$ & $2.3 \pm 0.89$ \\
\hline
\end{tabular}

this hypothesis should be evaluated in experimental studies initially.

The first laparoscopic repair technique was introduced with primary repair and omentoplasty in 1989 . ${ }^{[25]}$ After this approach, many different methods were performed, such as omental patch with fibrin plug, ${ }^{[26]}$ repair with ligamentum teres hepatis, ${ }^{[27]}$ fibrin glue, ${ }^{[7]}$ omental patch application with stapler, ${ }^{[28,29]}$ and fibrin patch (TachoComb) ${ }^{[30]}$ The beneficial effects of fibrin on wound healing have been shown. ${ }^{[31]}$ It has been reported that laparoscopic fibrin glue application for duodenal ulcer perforation has similar postoperative results to primary repair or primary repair with omentoplasty. Additionally, fibrin glue application minimized the operating time. ${ }^{[6,7,24]}$ Easy application and effective barrier function are the main components that reduce operating time. Lau et al. ${ }^{[7]}$ suggested that sutureless repair of duodenal perforations is as safe as conventional techniques and is easy to learn for the treatment of the duodenal perforations that are smaller than $1 \mathrm{~cm}$.

Prior to the present study, no data were available about the effects of DuraSeal application for gastrointestinal perforations. We observed similar results regarding histopathological and hydroxyproline levels in all the experimental groups. When we evaluated the bursting pressure levels, conventional repair methods were safer and more secure than the sutureless repair techniques. The sutureless methods that we evaluated were shown to have no superior effects to conventional repair techniques. As a foreseeable result, suturing caused physical stability in the repaired area. The serosal surface, which is the most potent layer of the intestine, is closed with suturing. In sutureless repair, the defect is clogged with a chemical agent. Especially in the early phase of the wound healing process, the physical stability could be weaker in the repaired area. In clinical practice, physical straight is not a sine qua non parameter of the repair of duodenal perforation. In the literature, some methods, such as Taylor's method, which require no suture application or surgical intervention, have been described for the treatment of duodenal perforations. In Taylor's method, nasogastric aspiration, fluid resuscitation, parenteral broad-spectrum antibiotics, and antisecretory drugs are used. Taylor's method is suggested as an alternative in selected cases of perforated gastroduodenal ulcers, the main advan- tage being the avoidance of anesthetic and surgical stress, with their potential morbidity and mortality. ${ }^{[32]}$ However, using an adhesive barrier that can repair perforations or leaks quickly and easily would be more logical for the surgeons than leaving the perforation untouched.

Fibrin glue is being used in clinical practice in the sutureless treatment of duodenal perforations. ${ }^{[7]}$ All the procedures evaluated in this study have been used in clinical practice, except DuraSeal. Hydroxyproline levels and histological evaluation were similar in all the experimental groups. This result reminds us that there was no difference between groups during the wound healing process. According to this result, we suggest that DuraSeal can be considered an alternative material for the sutureless treatment of duodenal perforation, like fibrin glue, because we did not observe any harmful or worse effect of DuraSeal when compared with fibrin glue. However, this hypothesis must be supported by new studies that are planned with other wound healing markers and different designs.

\section{REFERENCES}

1. Sonnenberg A. Temporal trends and geographical variations of peptic ulcer disease. Aliment Pharmacol Ther 1995;9:312.

2. Noguiera C, Silva AS, Santos JN, Silva AG, Ferreira J, Matos E, et al. Perforated peptic ulcer: main factors of morbidity and mortality. World J Surg 2003;27:782-7.

3. Siu WT, Leong HT, Law BK, Chau CH, Li AC, Fung KH, et al. Laparoscopic repair for perforated peptic ulcer: a randomized controlled trial. Ann Surg 2002;235:313-9.

4. Christensen S, Riis A, Nørgaard M, Thomsen RW, Tønnesen EM, Larsson A, et al. Perforated peptic ulcer: use of pre-admission oral glucocorticoids and 30-day mortality. Aliment Pharmacol Ther 2006;23:45-52.

5. Wu CY, Wu CH, Wu MS, Wang CB, Cheng JS, Kuo KN, et al. A nationwide population-based cohort study shows reduced hospitalization for peptic ulcer disease associated with $\mathrm{H}$ pylori eradication and proton pump inhibitor use. Clin Gastroenterol Hepatol 2009;7:427-31.

6. Lau WY, Leung KL, Zhu XL, Lam YH, Chung SC, Li AK. Laparoscopic repair of perforated peptic ulcer. Br J Surg 1995;82:814-6.

7. Lau WY, Leung KL, Kwong KH, Davey IC, Robertson C, Dawson JJ, et al. A randomized study comparing laparoscopic versus open repair of perforated peptic ulcer using suture or sutureless technique. Ann Surg 1996;224:131-8.

8. Bhanot S, Alex JC. Current applications of platelet gels in facial plastic surgery. Facial Plast Surg 2002;18:27-33.

9. Joch C. The safety of fibrin sealants. Cardiovasc Surg 
$2003 ; 11: 23-8$.

10. Akgün A, Kuru S, Uraldi C, Tekin O, Karip B, Tug T, et al. Early effects of fibrin sealant on colonic anastomosis in rats: an experimental and case-control study. Tech Coloproctol 2006;10:208-14.

11. van der Ham AC, Kort WJ, Weijma IM, van den Ingh HF, Jeekel H. Effect of antibiotics in fibrin sealant on healing colonic anastomoses in the rat. Br J Surg 1992;79:525-8.

12. Kaya C, Demir U, Coşkun H, Kalyoncu A, Gündüz B, Eroğlu $\mathrm{T}$, et al. Comparison of repair techniques in rat duodonal perforations: simple closure, simple closure and omentoplasty, and fibrin tissue adhesive. Ulus Travma Acil Cerrahi Derg 2004;10:11-6.

13. Papavramidis TS, Kotzampassi K, Kotidis E, Eleftheriadis EE, Papavramidis ST. Endoscopic fibrin sealing of gastrocutaneous fistulas after sleeve gastrectomy and biliopancreatic diversion with duodenal switch. J Gastroenterol Hepatol 2008;23:1802-5.

14. Papavramidis ST, Eleftheriadis EE, Papavramidis TS, Kotzampassi KE, Gamvros OG. Endoscopic management of gastrocutaneous fistula after bariatric surgery by using a fibrin sealant. Gastrointest Endosc 2004;59:296-300.

15. Babor R, Talbot M, Tyndal A. Treatment of upper gastrointestinal leaks with a removable, covered, self-expanding metallic stent. Surg Laparosc Endosc Percutan Tech 2009;19:1-4.

16. Silecchia G, Boru CE, Mouiel J, Rossi M, Anselmino M, Morino $\mathrm{M}$, et al. The use of fibrin sealant to prevent major complications following laparoscopic gastric bypass: results of a multicenter, randomized trial. Surg Endosc 2008;22:2492-7.

17. Preul MC, Bichard WD, Spetzler RF. Toward optimal tissue sealants for neurosurgery: use of a novel hydrogel sealant in a canine durotomy repair model. Neurosurgery 2003;53:118999.

18. Hagberg RC, Safi HJ, Sabik J, Conte J, Block JE. Improved intraoperative management of anastomotic bleeding during aortic reconstruction: results of a randomized controlled trial. Am Surg 2004;70:307-11.

19. Marien BJ, Raffetto JD, Seidman CS, LaMorte WW, Menzoian JO. Bovine pericardium vs dacron for patch angioplasty after carotid endarterectomy: a prospective randomized study. Arch Surg 2002;137:785-8.
20. Bennett SL, Melanson DA, Torchiana DF, Wiseman DM, Sawhney AS. Next-generation hydrogel films as tissue sealants and adhesion barriers. J Card Surg 2003;18:494-9.

21. Grotenhuis JA. Costs of postoperative cerebrospinal fluid leakage: 1-year, retrospective analysis of 412 consecutive nontrauma cases. Surg Neurol 2005;64:490-4.

22. Kivirikko KI, Laitinen O, Prockop DJ. Modifications of a specific assay for hydroxyproline in urine. Anal Biochem 1967; 19:249-55.

23. Bertleff MJ, Liem RS, Bartels HL, Robinson PH, Van der Werff JF, Bonjer HJ, et al. The "stamp method": a new treatment for perforated peptic ulcer? Surg Endosc 2006;20:7913.

24. Kubota M, Okuyama N, Hirayama Y. A new method to close an intestinal wall defect using fibrin glue and polyglycolic acid felt sealant. J Pediatr Surg 2007;42:1225-30.

25. Nathanson LK, Easter DW, Cuschieri A. Laparoscopic repair/peritoneal toilet of perforated duodenal ulcer. Surg Endosc 1990;4:232-3.

26. Mouret P, François Y, Vignal J, Barth X, Lombard-Platet R. Laparoscopic treatment of perforated peptic ulcer. Br J Surg 1990;77:1006.

27. Costalat G, Dravet F, Noel P, Alquier Y, Vernhet J. Coelioscopic treatment of perforated gastroduodenal ulcer using the ligamentum teres hepatis. Surg Endosc 1991;5:154-5.

28. Darzi A, Cheshire NJ, Somers SS, Super PA, Guillou PJ, Monson JR. Laparoscopic omental patch repair of perforated duodenal ulcer with an automated stapler. Br J Surg 1993;80:1552.

29. Nassar A. Laparoscopic omental patch repair of perforated duodenal ulcer with automated stapler. $\mathrm{Br}$ J Surg 1994;81:1393.

30. Sim AJW, Ashaal YE, Ramadan K, et al. Laparoscopic repair of perforated duodenal ulcers using collagen fleece coated with fibrin glue. Min Inv Ther 1995:4;215-7.

31. Feld RS, Sullivan E, Morrison P. Thrombin injection for failed stent graft repair of perforated atherosclerotic aortic ulcer. J Vasc Surg 2003;37:194-7.

32. Dascalescu C, Andriescu L, Bulat C, Danila R, Dodu L, Acornicesei M, et al. Taylor's method: a therapeutic alternative for perforated gastroduodenal ulcer. Hepatogastroenterology 2006;53:543-6. 